\title{
EXPERIENCE AT HOME AND INNOCENCE ABROAD: SOCIAL AND CULTURAL CAPITAL IN MACHADO DE ASSIS'S ESAÚ E JACÓ AND HENRY JAMES'S THE AMBASSADORS
}

\author{
Bethany Beyer \\ University of California \\ Los Angeles, Califórnia, Estados Unidos
}

\begin{abstract}
This study examines two literary worlds fashioned by epic authors Machado de Assis and Henry James. In the novels Esaú e Jacó (1904) and The Ambassadors (1903), the writers explore the theme of ambassadorship. In these two texts, key characters act as emissaries. Councilor Aires, Lambert Strether, and Sarah Pocock discover that ambassadorial service brings with it many complications. Each of them fulfills his or her mission in a particular way and does so with differing motives. For these three individuals, access to and interpretation of information becomes decisive in fulfilling their respective commissions. This information circulates in distinct ways, yet the ability to access and understand the information depends on each ambassador's social and cultural "capital", as can be seen in the theories of Pierre Bourdieu.
\end{abstract}

Keywords: Henry James, Machado, Bourdieu

Experiência em casa e inocência no exterior: o capital social e cultural em Esaú e Jacó de Machado de Assis e The Ambassadors de Henry James

Resumo: Este estudo examina dois universos literários criados por Machado de Assis e Henry James. Nos romances Esaú e Jacó (1904) e The Ambassadors (1903), os autores exploram a condição do "embaixador", e nas duas obras os personagens agem como emissários. O conselheiro Aires, Lambert Strether e Sarah Pocock descobrem as complicações dessa função e cada um deles desempenha sua missão de maneira singular e com motivações diferentes. Para esses três indivíduos, o acesso à informação e à sua interpretação torna-se fator decisivo nas suas comissões, na medida em que a informação circula de forma distinta, mas a habilidade de acessá-la e compreendê-la depende do "capital" social e cultural de cada emabaixador, como observado nas teorias de Pierre Bourdieu.

Palavras-chave: Henry James, Machado, Bourdieu

Near the end of their careers, two prolific authors, Joaquim Machado de Assis and Henry James, both wrote novels in which key characters agree to act as ambassadors 
on behalf of personal acquaintances. Although separated by language, nationality, and geography, the two writers shared their aim of exploring the implications, complications, and repercussions of ambassadorship. The two texts provide a fruitful comparison since each ambassador's access to and use of acquired information differs in the places-Brazil and Europe - where that knowledge proves valuable. The circulation of information in Machado's and James's novels becomes particularly noteworthy when understood in light of Pierre Bourdieu's concept of capital, which underscores the worth of knowledge and one's access to it. In these masterworks the writers reveal that effectually representing another person depends less on given instructions than on one's ability to accumulate and put capital to good use. While Machado's shrewd protagonist, conselheiro [Councilor] Aires, seemingly works to accomplish his own ends, James's perceptive hero, Lambert Strether, increasingly relies on his growing judgment to do his best; conversely, Strether's counterpart, Sarah Pocock, represents her deputator's interests to the letter.

Despite Machado's and James's contemporaneity, skill, and propensity to depict the internal rather than the external, especially in their later texts, only a handful of scholars have juxtaposed the authors' novels. John Gledson, Earl Fitz, Roberto Schwarz, and Marcelo Pen Parreira have focused on different points of comparison to bring Machado and James into conversation with one another, but much remains to be said with regard to comparing the writers' texts in general and Esau and The Ambassadors in particular. Produced late in Machado's career, in various ways Esaú e Jacó (1904) is characteristic of the author's later texts, which are set in late nineteenth-century Brazil and, generally speaking, "emphasiz[e] interiorized conflict, symbolically rendered characterizations, and controlled ambiguity". ${ }^{1}$ Esaú follows Memórias póstumas de Brás Cubas (1881), Quincas Borba (1891), and Dom Casmurro (1899), and precedes Memorial de Aires (1908), which similarly features the cosmopolitan conselheiro Aires. James's tour de force, The Ambassadors (1903), also falls chronologically near the end of its author's sizeable oeuvre. Representative of James's internationalist theme, it presents somewhat naive U.S. travelers who traverse the Atlantic to find continental "culture" -

${ }^{1}$ FITZ, Machado de Assis, p. 20. 
and often come away with unexpected insights and knowledge. The Ambassadors also showcases his "late style", frequently critiqued as being dense and more difficult to follow than earlier works, such as Portrait of a Lady (1881).

Esaú e Jacó (1904) tells the story of a well-to-do Rio de Janeiro family in the latter half of the nineteenth-century, consisting of Santos and Natividade, and their identical twin sons, Paulo and Pedro. Despite their bond, like their biblical namesakes the brothers develop an adversarial relationship. They also hold opposing political views: Pedro supports the continuance of Brazilian monarchism, and Paulo, the advent of republicanism. Concerned over her sons' growing mutual enmity, Natividade seeks assistance not from her husband, but from her astute old friend and admirer, conselheiro Aires, a retired diplomat. She tells him intimate family details and invites Aires into the familial circle. He essentially replaces the twins' father, basing this move on the supposition that he is indeed "melho[r] do que [o] verdadeir[o]" (better than the real [father] $){ }^{2}$ Natividade essentially deputizes the seasoned diplomat, now living in Rio, and asks him to intervene to keep the family peace. Aires assents to her plea, yet his subsequent actions beg the question of whose interests he really represents.

In contrast to Machado's tale of a world-weary diplomat, James's The Ambassadors (1903) presents Lambert Strether, in many ways conselheiro Aires's opposite. An intelligent, sensitive individual of limited means and often-quashed hopes, Strether receives a commission from his redoubtable patron (and fiancée) Mrs. Newsome. He must go to France and "rescue" her grown son Chad from the wiles of Parisian life (including a romantic entanglement with the lovely Madame de Vionnet) and bring the heir home to the family business in Woollett, Massachusetts. ${ }^{3}$ Strether accedes to his betrothed's wishes, but finds himself caught between fidelity and reality, and fails to precisely follow her instructions. Mrs. Newsome then deploys another ambassador, her daughter, Sarah Pocock, who will presumably act exactly as her mother would.

\footnotetext{
${ }^{2}$ Idem, p. 92.

${ }^{3}$ Woollett, Massachusetts is used throughout the book as a metonym for the Newsome-Pocock family members and their values and opinions.
} 
The ability to access and construe information proves critical for these "ambassadors" that attempt to fulfill their commissions. This information circulates in both conventional and unconventional forms, including notes and letters, presentiment and divination, and rumor and gossip. Yet each ambassador's ability to access relevant information and interpret it greatly depends on his or her cultural and social capital, in Bourdieusian terms. Cultural capital refers to intellectual wealth, whereas social capital places a high value on the use of social networks for upward mobility. Strether, Sarah Pocock, and Aires all find themselves having to rely on such capital to obtain information.

Distance and proximity affect what information the ambassadors have - and need. For Sarah Pocock and Strether, the two emissaries sent abroad, their heavy reliance on letters - particularly those detailing Mrs. Newsome's party line - demonstrates their deficiency of cultural and social capital overseas. While Mrs. Pocock consistently draws on domestic written counsel and mostly spurns other sources, over time Lambert Strether comes to depend less on such epistolary instructions and more on information gained through presentiment and gossip - information he deems relevant. This shift occurs largely as a result of the social capital he acquires though the people he meets - including Maria Gostrey, Chad Newsome, and Madame de Vionnet - and the cultural capital he accrues in Paris. In this way he resembles Councilor Aires, who reads into rumor while trusting his own judgment, not instructions. Wealthy and well-connected, Aires often makes use of long-standing personal relations. The conselheiro's abundance of social and cultural capital ensures that he wields the most "symbolic capital" (prestige, honor, and recognition): unlike the other ambassadors, he is an autonomous, successful promoter of his own interests, and draws upon his strengths primarily for his own purposes.

\section{Culture and Capital}

The flow of information in the Machadian and Jamesian worlds takes on a distinct meaning when seen through the lens of Bourdieu's concept of capital, which 
highlights the value of being in the know. In "The Forms of Capital" Bourdieu posits the impossibility of "account[ing] for the structure and functioning of the social world unless one reintroduces capital in all its forms and not solely in the one form recognized by economic theory". ${ }^{4}$ Although Bourdieu naturally refers to a real "social world", those created by James and Assis are fictional; however, the authors seek to re-create a "real" world governed by natural laws, inner power relations, and human emotions. The societal norms and structures in the fictive worlds of Strether, Sarah Pocock, and conselheiro Aires resonate with those analyzed by Bourdieu. While the sociologist recognizes many forms of "capital," the most relevant to this study include social and cultural capital, which in turn endow the possessor with "symbolic power". ${ }^{5}$ Bourdieu defines cultural capital as the synthesis of a person's education, knowledge of, and attitudes toward the surrounding world, which includes possessing "cultural goods" such as books and instruments. ${ }^{6}$ Social capital, on the other hand, requires "membership in a group," and "more or less institutionalized relationships of mutual acquaintance and recognition". 7 Several forms of capital — including economic capital — prove crucial for these characters that dwell in worlds governed by many types of exchanges. Although access to wealth allows the envoys to travel abroad and mix with the elite, their resources of cultural and social capital allow them to gain pertinent information.

Even before their missions, the three ambassadors possess social and cultural capital in abundance. Mrs. Newsome's deputies, Strether and Sarah Pocock, are capitalrich in their home city of Woollett, Massachusetts, with comfortable surroundings and community ties. As the editor of the humble yet noted Review, Strether enjoys a certain social standing in his native place: his position reflects his ties to an important "Woollett swell," Mrs. Newsome, and access to her resources. ${ }^{8}$ He masks his ineffectual life, the

\footnotetext{
${ }^{4}$ BORDIEU, Forms of Capital, p. 242.

${ }^{5}$ JOHNSON, Editor's Introduction: Pierre Bourdieu on Art, Literature and Culture, p. 7.

${ }^{6}$ Idem, p. 243-248.

${ }^{7}$ Idem, p. 248.

${ }^{8}$ JAMES, The Ambassadors, p. 66.
} 
"wreck of hopes and ambitions, the refuse-heap of disappointment and failures", ${ }^{9}$ by having his name on the Woollettian Review's green cover and by courting the wellconnected Widow Newsome. Yet, as Strether undertakes the mission to rescue her son Chad from a "wicked woman" ${ }^{10}$ and from an "unremunerative" life in France, ${ }^{11}$ he feels unsettled despite directions from headquarters. His clear-cut instructions represent Mrs. Newsome's attempt to narrate his "Paris mission without digression or lacunae". ${ }^{12}$ Away from his patron, his cultural and social capitals diminish. In Europe, Lambert Strether undergoes a "cycle of unexpected experience"13 in an effort to "perform a mission that restores propriety as much as property, sexual as well as commercial fidelity". ${ }^{14}$ Although his assignment is straightforward, its execution becomes complicated. Despite his education, command of French, and previous trip to Europe long ago, he feels out of his element, an innocent abroad. As Strether admits to the worldly wise Maria Gostrey, he hopes that she does not think him "too hopeless". ${ }^{15}$ By placing himself in her capable hands and availing himself of her connections, Strether opens himself to the creation of a Bourdieusian web of "mutual acquaintance and recognition" upon which he will come to rely. ${ }^{16}$

Similarly, as an ambassador Sarah Pocock, née Newsome, enters the "foreign" Parisian world in which she has few ties. As a married woman of means and position, she lacks for nothing in the U.S. Blessed with a commanding personality-Strether feels "perhaps a little afraid of her"17 — she comes to Paris with guns blazing. In this continental "Babylon" she does not enjoy the same influence as at home, and she refuses to draw on Strether's connections. Sarah instead relies on her wealth, her brought-along

${ }^{9}$ Ibidem.

${ }^{10}$ Idem, p. 59.

${ }^{11}$ FORSTER, The Ambassadors, p. 73.

${ }^{12}$ KOHAN, "Rereading the Book in Henry James's The Ambassadors", p. 375.

${ }^{13}$ LUBBOCK, The Point of View: The Ambassadors, p. 40.

${ }^{14}$ RIVKIN, "The Logic of Delegation in The Ambassadors", p. 823.

15 JAMES, cit., p. 29.

${ }^{16}$ BORDIEU, cit., p. 248.

${ }^{17}$ JAMES, cit., p. 60. 
clique, and her Woollettian values. Unlike Strether, Sarah acts as one of Mrs. Newsome's "perfect representatives", a "transparent medium for her principal's intent", ${ }^{18}$ a kind of double. ${ }^{19}$ The daughter stubbornly and faithfully adheres to instructions, donning a diplomatic mask and blinding herself to what Strether sees, such as Chad's "improvement": she regards the latter's metamorphosis as a "hideous" development. ${ }^{20}$ Sarah largely eschews Chad's colleagues. She instead allies with the respectable, hidebound Waymarsh - another traveler from Masachussetts and Strether's friend-knowing that Waymarsh possesses inside information and shares her views. Despite her confederate Waymarsh's recommendations, and her own determination, Mrs. Pocock's social and cultural wealth do not serve her well in Paris. She finds herself at a loss to contend with Chad in his changed state. Strether even discerns that Sarah fears Chad, perhaps because he is so socially and culturally rich, and can oppose her. ${ }^{21}$ In the "field" of Paris, with its rules and social mores, her homegrown savoir faire, like Strether's, proves inadequate to "play the game" as Bourdieu would say. ${ }^{22}$ Successfully maneuvering the French socialscape and accessing information requires new strategies and careful negotiations.

Such maneuverings come naturally to conselheiro José da Costa Marcondes Aires. The diplomat's European odyssey has only added polish to his persona. Rather than going abroad to fulfill a commission, Aires retires in Brazil. This homecoming marks - he supposes-his withdrawal from diplomacy. ${ }^{23}$ The seasoned diplomat's

\footnotetext{
${ }^{18}$ KOHAN, cit., p. 381, 389.

${ }^{19}$ Rivkin makes the point that Mrs. Newsome expects this kind of "likeness, without a difference" from all her "ambassadors". RIVKIN, cit., p. 824.

${ }^{20}$ JAMES, cit., p. 378.

${ }^{21}$ Idem, p. 386.

${ }^{22}$ JOHNSON, cit., p. 6, 8 .

${ }^{23}$ Tanner describes Aires as one who "does not do any fighting. He has withdrawn from the fray. He affects to be too old for passion, too indifferent for argument. He is an unbeliever who professes all beliefs; an ageing non-participant who has seen everything. He is an immensely wise observer, a kindly adviser, a devoted and scrupulous recorder of his city and his past. [...] Himself completely calm, he likes to stand and watch the restless strength and urge of the sea". TANNER, "Machado de Assis", p. 56. Yet, as the Councilor's actions show, he is far from an "ageing non-participant" in the lives of Natividade, Paulo, and Pedro.
} 
European odyssey has only added polish to his persona. Although his official duties have ended, in Rio his "personal power acquired by family networks...and honour" continues. ${ }^{24}$ Even at the midpoint of his career, Aires "trazia o calo do ofício, o sorriso aprovador, a fala branda e cautelosa" ${ }^{25}$ : he has mastered the art of diplomacy. Adept as he is at international relations, he could live in "qualquer cidade, era homem de todos os climas". ${ }^{26}$ Instead, he returns to Brazil; his suitcase full of letters and his "armário envidraçado, onde meteu as relíquias da vida," document a full life. ${ }^{27}$ The conselheiro's experiences and position make him a man "in demand", and in Rio he assimilates into an elite formed by "banqueiros, magistrados, ministros e latifundiários". ${ }^{28}$ These social ties, along with his education (he knows Greek, reads the classics, and has a thorough familiarity with European Romantic literature and music), endow him with great social and cultural capital, or symbolic power. Aires dwells in a world representative of many Machadian texts in which "there is a profound sense, nothing documentary, of status, of the duel of salons, of the movement of social strata, of the power of money. Gain, profit, prestige, the sovereignty of interest - these are the springs of action of his characters". ${ }^{29}$ Perhaps due to this influence, Natividade turns to the conselheiro when she seeks a solution to her son Paulo's political rebellion and her sons' mutual belligerence. Her motivation seems obvious: Aires is "um homem moderado, um homem de sociedade, hábil, fino, cauteloso, inteligente, instruído" ${ }^{30}$ and her husband has other concerns. Aires's wealth of cultural and social capital recommends him to her as the best possible representative to carry out her request, or so she assumes.

\footnotetext{
${ }^{24}$ FOWLER, Pierre Bourdieu and Cultural Theory: Critical Investigations, p. 5.

${ }^{25}$ ASSIS, Esaú e Jacó, p. 36.

${ }^{26}$ Idem, p. 64.

${ }^{27}$ Idem, p. 65-66.

28 PINHEIRO PASSOS, As sugestões do conselheiro: a França em Machado de Assis: Esaú e Jacó e Memorial de Aires, p. 11.

${ }^{29}$ CANDIDO, An Outline of Machado de Assis, p. 117.

${ }^{30}$ ASSIS, Esaú e Jacó, p. 74.
} 


\section{(Mis)reading letters}

Letters, notes, and other written correspondence play an important role in Esaú e Jacó, as well as in The Ambassadors. In Esaú, information contained in written communications, whether instructions or simple correspondence, allows those possessing the writings to be "in the know". In this sense, letters are a form of capital. For each ambassador, gaining access to information and being able to use it proves significant. Yet, both access and "know-how" depend in large part upon the person's cultural and social capital: "reading" an epistle entails "reading into" it. Natividade first seeks Aires's help because of a worrisome letter she receives from her son Paulo revealing his support for Brazilian emancipation. Fearful of repercussions against him, she entreats Aires to be her agent due to his expertise, social position, and ability to read delicate situations. She instructs him, yet trusts that the conselheiro will faithfully represent her interests as he deems fit.

In contrast, in The Ambassadors Mrs. Newsome chooses her emissaries because she presumes they will follow her epistolary instructions and will read situations as she would. Strethers discovers that noncompliance results in a conspicuous lack of correspondence. Sarah and her mother maintain a "'logocentric'" relationship while apart, ${ }^{31}$ but as Strether begins to rely on his own evolving social and cultural views, transatlantic communiqués to him peter out. His move toward autonomy begins early: upon receiving Mrs. Newsome's first letters, his distance from the writer makes him feel "so free", as though he has escaped (Strether is vague as to what he has escaped). ${ }^{32}$ At this point he has already begun to push beyond the letters, eager as he is to forge his own capital and be "led forth into the world" by Maria and others. ${ }^{33}$ As his social capital sinks in Massachusetts, it rises in Europe.

On the other hand, the well-connected, well-informed Aires may use letters as a source of information, but he eschews the instructions associated with them. In this sense,

\footnotetext{
${ }^{31}$ KOHAN, cit., p. 389.

32 JAMES, cit., p. 77.

${ }^{33}$ Idem, p. 28.
} 
his symbolic power exceeds the capital that letters offer. Rather, he uses them as a means to gain insights into situations and people, often for his own benefit. For example, Paulo's worrisome letter to his mother spurs Natividade to seek Aires's counsel. The correspondence contains information that she conceals from her husband, and reveals to the diplomat. Yet, Aires never actually reads the letter. Natividade explains her situation and in essence he "reads" between the lines of her emotional tale: "contou primeiro a rivalidade dos filhos... repetiu-lhe a frase da carta e perguntou o que cumpria fazer mais útil". ${ }^{34}$ Through additional conversation he discerns the state of affairs; he infers that the twins will be rivals in love and in politics, although Natividade shrinks from the possibility: "Imagine em amores, diga logo. Mas não é propriamente para este caso...". 35 Through long experience he knows that love only intensifies competition, something that no letter could reveal. Later events prove Aires right: the twins fight over the beautiful Flora and over politics. Whether or not Natividade agrees with the conselheiro's prediction, she recognizes his clout, and deputizes him.

In another instance Flora's father, Batista, seeks the Councilor's advice. First, in an attempt to foster their conversation, he insists that Aires view a collector's item- $\mathrm{a}$ timeworn letter from the famed Portuguese prime minister Pombal to his minister in Holland. Again, Aires does not read the letter, since his host admits that "é importante, mas longa". ${ }^{36}$ Instead, the document provides a pretext to draw upon the diplomat's wisdom. Batista has political aspirations and wants career advice and support from Aires. Before seeking backing, Batista places Pombal's epistle in an envelope for Aires to take home, and addresses it "'Ao meu excelentíssimo amigo conselheiro Aires"'. ${ }^{37}$ In doing so, Batista in essence figures as Pombal, and "deputizes" Aires. Aires neither needs nor esteems the letter, a tangible piece of cultural capital; his symbolic power extends even to the realm of Brazilian politics. He has plenty of capital, and has become a "fino observador da comédia humana, homem viajado e vivido, com muito de si para contar, se

${ }^{34}$ ASSIS, Esaú e Jacó, p. 72.

${ }^{35}$ Idem, p. 74.

${ }^{36}$ Idem, p. 99.

${ }^{37}$ Idem, p. 99-100. 
quisesse". ${ }^{38}$ Aires does not need to read history since he has lived it, and continues to subtly influence it.

\section{Knowledge and the oracle}

While Aires avoids reading letters, Strether gradually realizes that the flow of letters from his patron has ended. Of course, neither man feels that the written word encapsulates all information; in both Rio and Paris knowledge gained via oracles and presentiment also matters greatly. Again, having such information allows them to be "in the know," and to gain symbolic power through possessing such particulars, whether they speak to "oracles" or interpret rumor. Kohan asserts that Strether's "emerging centrality" is "achieved not through a 'logocentric' domination of affairs but through his rigorous lack of specific knowledge and his negative realization that he knows either everything... or nothing". ${ }^{39}$ Yet, Strether's centrality or growing importance comes not from a lack of knowledge, but rather from his increasing cultural and social capital. As this capital grows, his access to knowledge improves, and the logocentrism of his relationship with Mrs. Newsome decreases.

As Strether enters unfamiliar territory — both spatially and socially — the value of what he does know lessens, outweighed by the worth of what he does not know. He comes to rely on his "guide" in Europe, Maria Gostrey, who understands much and at times "sees" what others do not, as if she were gifted with second sight. In this sense, rather than viewing her as an "expert on ambassadorial logic", as Rivkin suggests, ${ }^{40}$ she can be understood as a kind of seer. Strether admits early on that he is "almost afraid" of Maria's "illuminations", or ability to discern what he truly feels. ${ }^{41}$ Yet, as Yeazell points out, from the beginning he can understand Maria and interpret her utterances:

\footnotetext{
${ }^{38}$ PAES, Gregos e baianos: ensaios. p. 13.

${ }^{39}$ KOHAN, cit., p. 390.

${ }^{40}$ RIVKIN, cit., p. 824.

${ }^{41}$ JAMES, cit., p. 32.
} 
Strether has known Maria Gostrey for less than twenty-four hours, but already she and he have become verbal collaborators, joined in the "remorseless analysis" of Waymarsh, Woollett, and Strether himself . . . this pair often talk in sentence fragments, extending and completing one another's thoughts as if they were not so much separate persons as parts of a single self. ${ }^{42}$

Strether's ability to form part of a "single self" with Maria adds to his ability to "see" Paris from an insider's point of view. Their "verbal" collaboration and "'remorseless analysis"" provide Strether with valuable knowledge, contributing to his awakening.

An important moment of realization occurs when he, Maria, and Waymarsh attend a theatrical performance. As they wonder at the absence of their anticipated guest, little Bilham, Maria experiences an "illumination." She realizes, with clear-cut certainty, that Bilham is in league with Chad, and is "acting...on [Chad's] daily instructions". 43 This sudden flash of insight helps Strether's comprehension of and ability to read the situation, but the passage's wording emphasizes Maria's uncanny abilities.

"They've got you," she portentously answered.

"Do you mean he $i s--? "$

"They've got you," she merely repeated. Though she disclaimed the prophetic vision she was at this instant the nearest approach he had ever met to the priestess of the oracle. The light was in her eyes. "You must face it now." ${ }^{44}$

Despite her disavowal of a prophetic gift, she nevertheless acts as a diviner. Even without the "second sight" she divines, or reads "all the signs and omens freely scattered in the world". ${ }^{45}$ Strether interprets her pronunciations, to his benefit. Sarah Pocock disdains Maria's company and ignores the latter's propheticality. Through Maria,

${ }^{42}$ YEAZELL, "Talking in James", p. 68.

${ }^{43}$ JAMES, cit., p. 115.

${ }^{44}$ Ibidem.

${ }^{45}$ WOOD, The Road to Delphi: The Life and Afterlife of Oracles, p. 20. 
Strether has access to information based neither on instructions nor on rumor: she can know much, and he profits from her insight.

Conselheiro Aires also knows a great deal, although his "oracular" knowledge is at first outshined by that of "real" oracles. When Aires receives his deputation from Natividade he is likely aware of her trip long ago, upon the birth of her sons, to consult the Cabocla, a fortuneteller in Rio. Natividade sought the clairvoyant's foresight into the course of her newborn sons' lives. The mother believes in her as a "medium" through which the "god, a personal or personified agency" could speak: ${ }^{46}$ she acts as an envoy from divinity. Yet, to ensure a "good" outcome (the narrative voice suggests) Natividade compliments the Cabloca in the latter's hearing. The Cabocla's subsequent words fill the mother with great expectations: she assures Natividade that "Seus filhos serão gloriosos!". ${ }^{47}$ All oracles, as the narrator points out, "têm o falar dobrado", ${ }^{48}$ but Natividade chooses to believe that the Cabocla's predictions are weighted in her sons' favor and are genuine. After all, "Pessoas da sociedade falavam dela a sério", ${ }^{49}$ including many of Natividade's friends. Other acquaintances, and even her husband, Santos, believe in another "oracle", the Spiritualist Plácido. The espiritista reinterprets the Cabocla's prophecies, to Santos's satisfaction. These conjectures lead to further conjecture: "These oracles stimulate speculations about the significance of the twins' antagonism and its relationship to their predicted future as 'grandes homens"'. ${ }^{50}$ At first kept quiet, these predictions eventually become common knowledge.

Although Aires believes in neither the Cabocla nor Plácido, he knows how to use the information that comes from them. In fact, he himself could be considered oracular with regard to Flora. As Peixoto argues, "Aires sees more deeply into the future of the characters than either of the 'oracles' - the peasant girl or the spiritualist Plácido and has a keener insight into the rivalry over Flora and her hesitant nature than either the

${ }^{46}$ Idem, p. 23.

${ }^{47}$ ASSIS, Esaú e Jacó, p. 18.

${ }^{48}$ Idem, p. 19.

${ }^{49}$ Idem, p. 31.

${ }^{50}$ PEIXOTO, "Aires as Narrator and Aires as Character in Esaú e Jacó", p. 83. 
twins or the girl herself". ${ }^{51}$ He demonstrates this ability when he essentially reads Flora's mind. While attending a ball graced by royalty, she imagines the unencumbered life of a princess. The diplomat senses and then speaks Flora's feelings aloud, as a diviner might. He says to her, "Toda alma livre é Imperatriz", illuminating her inner-most thoughts. ${ }^{52}$ No one else possesses such ability. His insight - like Maria's - allows him to eschew letters and fortunetellers, and to instead rely on his own perception. Those with access to oracular information, like Aires, find that presentiment and illuminations serve them well in their diplomatic roles.

\section{Rumors and repercussions}

Aside from letters and oracles, other sources of info-gossip and rumor-also prove critical for each ambassador. In Paris, newcomer Lambert Strether knows few people and little about the situation at hand. Yet, he gains access to Maria's knowledge, consisting of her insight and conjecture, and her piecing together what she hears. As an early scene notes, "There were things of which she would really perhaps after all have heard; and she admitted...that she was never quite sure of what she heard as distinguished from things such as, on occasions like the present, she only extravagantly guessed". ${ }^{53}$ In fact, she has heard much, but has extrapolated even more. Although not of high social standing, Maria has a wide circle of contacts in Europe. Through her and through his newfound Parisian acquaintances - Chad, Madame de Vionnet, little Bilham, Miss Barrace-Strether can access information in order to comprehend Chad's situation. This access demonstrates his growing social capital. His entrée into society also buys him time to consider his course of action, since he reports all that he learns (as he sees it) to Mrs. Newsome.

\footnotetext{
${ }^{51}$ Idem, p. 85.

${ }^{52}$ ASSIS, Esaú e Jacó, p. 90.

${ }^{53}$ JAMES, cit., p. 59.
} 
Yet, information built upon rumor and gossip proves unstable. For example, little Bilham's claim that Madame de Vionnet and Chad's attachment is "virtuous" could be (mis)understood in various ways. As Yeazell explains, "Parisian talk thus educates Strether even as it seems to dissemble, for a sufficiently ambiguous language ensures that no hasty judgments can in fact be made, that all possibilities of vision and feeling must remain open". ${ }^{54}$ The performance going on before his eyes simultaneously enchants, blinds, and challenges Strether. His gossip-filled letters to Mrs. Newsome are accordingly biased, and although he seems to be "in the know", he only knows in part. At a critical juncture his oracle-guide, Maria, leaves Paris; as she confesses, she wishes to "keep out of the business". ${ }^{55}$ He feels Maria's absence keenly, and resorts to his own resources to read into gossip.

Even as Maria abandons Strether, another of his colleagues remains and also engages in gossip. The ever-present Waymarsh, Strether later deduces, sends his own gossip-filled missive to Woollett, revealing the extent of Strether's "going native". The purported letter results in Sarah Pocock's speedy arrival in France. Since Waymarsh does not admire Parisian ways as Strether does, the first man disapproves of Chad's situation. The rumors to which Waymarsh has access only confirm his already made-up mind. Due to his "allegiance" to the Newsome cause, while Strether's social capital falls in Wollett, Waymarsh's rises. This change becomes most apparent when Sarah arrives and Waymarsh, not Strether, becomes her confidant. The original ambassador is entirely cut off from Woollett's strategy. Sarah flatly refuses to reveal information at her disposal and tells Strether: "My instructions from Mrs. Newsome are, if you please, my affair". ${ }^{56}$ In time, Waymarsh knows "everything" that headquarters wishes, ${ }^{57}$ while Strether must continue his mission largely on his own.

In contrast, the gossip that fills conselheiro Aires's world perhaps does not carry with it Parisian intrigue, but it whispers of "coisas futuras" and change. Aside from the

\footnotetext{
${ }^{54}$ YEAZELL, cit., p. 70.

55 JAMES, cit., p. 182.

${ }^{56}$ Idem, p. 374.

${ }^{57}$ Idem, p. 368.
} 
Cabocla's predictions, which become gossip in their retelling, political ambition and republicanism fill the city with rumor. In the chapter aptly titled "Um segredo," Flora learns from Pedro of her father's possible political promotion. She tells Aires in hopes of forestalling the promotion, which would require her family to move, but her strategy backfires. Aires utilizes the gossip to successfully accomplish his own ends. The conselheiro praises "a nossa organização política" ${ }^{58}$ for its usefulness in taking Flora away from Paulo and Pedro, as he desires. The next day change is in the air. As Aires traverses the city he pieces together the (exaggerated) news of revolt, only to put it in its proper perspective. Whatever the political or personal situation, the diplomat uses the information he gains to accomplish his designs.

Still, the diplomat's actions beg the question: what precisely are those designs? Critics interpret Aires differently. Peixoto explains him as follows: "Retired professionally from active life and personally uninvolved, he takes the passive role of "conselheiro". 59 Paes describes the character in Memorial de Aires, which coincides chronologically with Esaú, as demonstrating a "permanente ambiguidade de atitudes em relação aos conflitos e aos protagonistas do Memorial, ambiguidade típica da sua índole de mediador diplomático; do seu sentido de relatividade das coisas". ${ }^{60}$ Monteiro also views the Memorial character as "desinteressado" ${ }^{61}$; however, with reference to Esaú, Gledson cautions against transforming the conselheiro into "outro personagem tão inútil e limitado quanto ao resto". ${ }^{62}$ Aires may seek to avoid "controvérsia", ${ }^{63}$ but he is hardly "passive" or "detached", although he can be "ambiguous". Instead, he actively works to bring about his own ends. His diplomatic experience has indeed made him "aguçado". He seemingly accepts his deputation from Natividade, and later tacitly promises Flora to also

\footnotetext{
${ }^{58}$ ASSIS, Esaú e Jacó, p. 109.

${ }^{59}$ Idem, p. 87.

${ }^{60}$ PAES, cit., p. 23.

${ }^{61}$ MONTEIRO, "Um sonho machadiano", p. 459

${ }^{62}$ GLEDSON, Machado de Assis: Ficção e História, p. 210.

${ }^{63}$ ASSIS, Esaú e Jacó, p. 37.
} 
represent her interests: "se achar algum recurso, tentarei o negócio". ${ }^{64}$ Yet, his ambiguity shows a skill for "equivocation and delay". ${ }^{65}$ The conselheiro really works for neither woman, and disregards their instructions.

Although Natividade wishes him to help her sons, to "fazê-los unidos", ${ }^{6}$ Aires emphasizes to her that his efforts will prove useless. Despite his learning, his social ties, and his experience, he cannot change what men call enmity. He accepts the bequest, but perhaps does so out of self-interest: he was once in love with Natividade. With regard to Flora, a similar motive might spur him on. The lovely Flora could be seen as a younger version of Natividade, the "one who got away". When Aires dissembles with regard to Flora he does so for his own purposes. He finds in the "inexplicável" young woman "um sabor particular" ${ }^{67}$ and seems to feel a special affinity for her. ${ }^{68}$ One way to understand this affinity could be as "Faustian lust". ${ }^{69}$ Considering Aires's position as a Mephistophelian figure in Memorial, desiring the young widow Fidélia, his interest in Flora could be seen in a similar, albeit sinister, light. ${ }^{70}$ If he indeed works toward and for such an end, then he is in effect his own agent, and hardly represents Natividade or Flora. Although the two women both turn to Aires because of his wealth of capitals, he essentially uses that wealth on his own behalf. If indeed the "most disagreeable, the most terrible, of [Machado's] characters are men of an impeccable bourgeois cut, perfectly geared into the mores of their class", ${ }^{71}$ then the impeccable, socially adept diplomat may be one of these terrible ones. In a society in which the other characters are "irresolutos e

${ }^{64}$ Idem, p. 9.

${ }^{65}$ WOOD, cit., p. 109.

${ }^{66}$ ASSIS, Esaú e Jacó, p. 74.

${ }^{67}$ Idem, p. 108.

${ }^{68}$ Peixoto mentions the "odd sort of spiritual identification" that Aires feels toward Flora, but the critic also extends this identification to Natividade and the twins, robbing it of lust. PEIXOTO, cit., p. 87.

${ }^{69}$ BORGES, Dain. "Self and Solitude in Machado de Assis' Late Novels, 1904-1908"

${ }^{70}$ Although Faust can be viewed as the figure in Goethe's text that "desires" women such as Margerete and Helen, Mephistopheles experiences desire as well, as Part II Act V demonstrates. Aires's feelings can perhaps best be understood in his wish-fulfilling dream about Fidélia in ASSIS, Memorial de Aires, p. 43.

${ }^{71}$ CANDIDO, cit., p. 117. 
incapazes de agirem por si mesmos", ${ }^{72}$ Aires, who acts for himself, could be considered king.

Strether learns to act for himself, but arguably only near the end of his European odyssey, when he has acquired more of the social and cultural capital that he lacked. As Mrs. Newsome's envoy, his express purpose is to bring Chad home. Yet, he also adopts another mission, that of working in Madame de Vionnet's interests. Strether's favorable report will help save her from "disrepute". ${ }^{73}$ Since he believes that the woman is "good" for Chad, at first his two purposes do not conflict, and his actions do not imply the "about-face" that Rivkin suggests. Strether's "ability to...think outside the confines of his immediate context" 74 allow him to view complexities that Sarah, with her "'pat"' answers, cannot see. ${ }^{75}$ By moving beyond those "confines" he transgresses his deputator's bounds. As he explains to Chad:

Mrs. Newsome...has imagined, did, that is, imagine, and apparently still does, horrors about what I should have found. I was booked, by her vision-extraordinarily intense, after all- to find them; and that I didn't, that I couldn't, that, as she evidently felt, I wouldn't - this evidently didn't at all, as they say, 'suit' her book. It was more than she could bear. That was her disappointment. ${ }^{76}$

The decision to work off-script may have its drawbacks, but it also has its rewards. Strether's solo outing into the French countryside, near the book's end, shows his transformation. He feels "success" at his happy decision to stray from Paris, and at his ability to finally speak the vernacular without fear. Previously, he has always dreaded speaking in front of others whose French surpasses his own. Now he enjoys "linguistic

\footnotetext{
72 GUIMARÃES, Os leitores de Machado de Assis: o romance machadiano e o público de literatura no século 19, p. 240

${ }^{73}$ KOHAN, cit., p. 388.

${ }^{74}$ Idem, p. 381.

${ }^{75}$ JAMES, cit., p. 376.

${ }^{76}$ Idem, p. 407.
} 
capital" and has the "social assurance of possessing a mastery of language". ${ }^{77}$ The trip symbolizes his independence, his growth, and the resources he has developed. He does not live "vicariously": ${ }^{78}$ he lives. When he stumbles upon Chad and Madame de Vionnet's lovers' tryst he "sees" the reality of the situation, but he does not react as either Woollett or Paris might expect. He comprehends the "deep, deep truth of the intimacy" between them $;{ }^{79}$ however, he also understands other truths, such as Mrs. Newsome's purposes and character. In a subsequent conversation with Maria, Strether observes that, "[Mrs. Newsome's] more than ever the same. But I do what I didn't before - I see her". ${ }^{80}$ This ability to "see" implies autonomy and an accumulation of social and cultural capital akin to that of Aires. The conselheiro may dissemble in fulfilling his duties, but he does so while acting as his own agent. Strether fulfills his duties, but does so while looking after the "best" interests, as he sees them, of those whom he represents.

All in all, the strategic deployment of the ambassadors' individual commissions brings varying results, and reveals the importance of information, connections, and the ability to play an ever-changing game. Sarah Pocock ostensibly succeeds in her stated goal of retrieving Chad: he will return to Massachusetts and leave his former life behind. Yet, her consistent reliance on Woollett's resources implies that Sarah's capital abroad hardly increases. Strether, on the other hand, moves beyond the strictures of "Mrs. Newsome's book", ${ }^{81}$ initially learning from Maria and then reading for himself the signs found in rumor-filled Paris. Although he will return home lacking in funds, he has grown rich is social and cultural capital, and his symbolic power has increased. Strether learns to see as he has not before seen, and to rely on his own judgment, not on that of his delegator. The powerful Aires, blessed with capital of all kinds, acts not as an agent for others, but for himself. He succeeds in accomplishing the goals that he comes to have, and uses all —information, rumor, insight — in this endeavor. Of the three ambassadors,

\footnotetext{
${ }^{77}$ FOWLER, cit., p. 28.

${ }^{78}$ RIVKIN, cit., p. 827.

79 JAMES, cit., p. 425.

${ }^{80}$ Idem, p. 468.

${ }^{81}$ Idem, p. 407.
} 
he most relies on the information that he gleans, a keen observer of humanity's successes and failures. While information proves vital to the envoys, each one's ability to access and use that information depends in large part on attitudes toward and accumulation of the capital at his or her disposal. The three live in worlds ruled by Bourdieusian exchanges of many kinds, and each finds that those transactions, whether at home or abroad, come at a price, be it low or high.

\section{Works cited:}

ASSIS, Machado de. Esaú e Jacó. 1904. São Paulo: Ática, 2006. Print. . Memorial de Aires. 1908. São Paulo: Ática, 2006. Print.

BORDIEU, Pierre. Forms of Capital. Trans. Richard Nice. Handbook of Theory and Research for The Sociology of Education. Ed. John G. Richardson. New York: Greenwood Press, 1986. 241-258. Print.

BORGES, Dain. "Self and Solitude in Machado de Assis' Late Novels, 1904-1908". Center for Brazilian Studies Lecture. UCLA Latin American Institute, Los Angeles. 22 May 2009.

CANDIDO, Antonio. An Outline of Machado de Assis. In: . On Literature and Society. Ed. and trans. Howard S. Becker. Princeton: Princeton UP, 1995. 104-118. Print.

FORSTER, Edward Morgan. The Ambassadors. In: EDEL, Leon (Ed.). Henry James: A Collection of Critical Essays. Englewood Cliffs, N.J.: Prentice-Hall, 1963. 72-78. Print.

FOWLER, Bridget. Pierre Bourdieu and Cultural Theory: Critical Investigations. London: Sage, 1997. Print.

GUIMARÃES, Hélio de Seixas. Os leitores de Machado de Assis: o romance machadiano e o público de literatura no século 19. São Paulo: Nankin/Edusp, 2004. Print.

JAMES, Henry. The Ambassadors. 1901. Ed. Adrian Poole. London: Penguin, 2008. Print. 
JOHNSON, Randal (Ed.). Editor's Introduction: Pierre Bourdieu on Art, Literature and Culture. The Field of Cultural Production: Essays on Art and Literature. Lanham, MD.: Rowman \& Littlefield, 2000. 1-25. Print.

KOHAN, Kevin. "Rereading the Book in Henry James's The Ambassadors". NineteenthCentury Literature 54.3 (1999): 373-400. Web.

LUBBOCK, Percy. The Point of View: The Ambassadors. In: EDEL, Leon (Ed.). Henry James: A Collection of Critical Essays. Englewood Cliffs, N.J.: Prentice-Hall, 1963. $37-$ 46. Print.

MONTEIRO, Pedro Meira. "Um sonho machadiano". Estudos avançados 15:42 (2001): 449-470. Web.

PAES, José Paulo. Gregos e baianos: ensaios. São Paulo: Brasiliense, 1985. Print.

PEIXOTO, Marta. "Aires as Narrator and Aires as Character in Esaú e Jacó". LusoBrazilian Review 17.1 (1980): 79-92. Web.

PEN PERREIRA, Marcelo. Estratégias do falso: realidade possível em Henry James e Machado de Assis. Diss. Universidade de São Paulo, 2007. Web.

PINHEIRO PASSOS, Gilberto. As sugestões do conselheiro: a França em Machado de Assis: Esaú e Jacó e Memorial de Aires. 2nd ed. São Paulo: Nankin Editorial, 2008. Print.

RIVKIN, Julie B. "The Logic of Delegation in The Ambassadors". PMLA 101.5 (1986): 819-831. Web.

TANNER, Tony. "Machado de Assis". The London Magazine. Apr. 1966: 41-57. Print.

WOOD, Michael. The Road to Delphi: The Life and Afterlife of Oracles. New York: Farrar, Straus and Giroux, 2003. Print.

YEAZELL, Ruth B. "Talking in James". PMLA 91.1 (1976): 66-77. Web.

Bethany Beyer is a Faculty Fellow in the UCLA Department of Spanish and Portuguese. Her areas of interest include musical and literary explorations of national and racial identity in the Americas, as well as Sephardic literary production. She has written on authors including José de Alencar and Cirilo Villaverde. Her current book project explores links between nationalism, literature, and dramatic musical works such as opera and zarzuela in the Americas during the nineteenth and early twentieth centuries. E-mail: $<$ bbeyer@ucla.edu> 
Recebido: 15/03/14

Aprovado: 16/04/2014

http://machadodeassis.net/revista/numero13/rev_num13_artigo06.pdf

Fundação Casa de Rui Barbosa - R. São Clemente, 134, Botafogo - 22260-000 - Rio de Janeiro, RJ, Brasil. 